\title{
INVESTIGATIONS ON PREVALENCE AND ANTIMICROBIAL RESISTANCE OF ENTEROHAEMORRHAGIC ESCHERICHIA COLI (EHEC) AMONG DAIRY FARMS IN THE NORTH PART OF THE REPUBLIC OF BULGARIA
}

\author{
Valentina Urumova, Mihni Lyutzkanov, Vladimir Petrov \\ Department of Veterinary Microbiology, Infectious and Parasitic Diseases \\ Faculty of Veterinary Medicine, Trakia University, 6000 Stara Zagora, Bulgaria
}

Received 10 May 2014; Received in revised form 29 September 2014; Accepted 20 October 2014

\begin{abstract}
Over a 2-year period, from January 2011 to May 2013, a total of 1094 faecal swab samples were collected from cattle at different age at 4 farms in North Bulgaria: Okorsh, Slavyanovo (Popovo municipality), Dobri dol and Trem. Out of them, 36 coli strains (3.3\%) positive in the E. coli O:157 antiserum agglutination test and identified by the BBL CRYSTAL identification system as belonging to the $E$. coli $\mathrm{O}: 157$ serotype were isolated. The distribution of isolates was as followed: $5(0.5 \%) E$. coli O:157 strains at the Okorsh dairy cattle farm, $7(0.6 \%)$ E. coli isolates at the Slavyanovo dairy farm, $16(1.5 \%)$ isolates at the Dobri dol farm and $8(0.7 \%)$ isolates at the Trem farm. Colibacteria exhibited $100 \%$ sensitivity to oxyimino-cephalosporins, gentamicin and enrofloxacin, and were resistant to ampicillin (19.4\%) and tetracycline (41.6\%). From the 15 strains resistant to tetracycline, 11 were isolated from the cows at Dobri dol, while the other 4 originated from the other three farms. The 7 ampicillin-resistant $E$. coli isolates were detected only at the Dobri dol cattle farm.
\end{abstract}

Key words: EHEC, cattle, antibiotic resistance

\section{INTRODUCTION}

In 1982, the identification of a new intestinal pathogen, E. coli $\mathrm{O} 157$ : $\mathrm{H} 7$, involved in the etiology of two disease outbreaks related to haemorrhagic colitis in humans, was reported (1). During the next decade, this intestinal bacterium was outlined as a pathogen of public health importance in a number of countries in North America and Europe. Soon after that, researchers described other coli serotypes of similar pathogenicity and the entire group was termed as enterohaemorrhagic $E$. coli (EHEC). E. coli $\mathrm{O} 157: \mathrm{H} 7$ is the most commonly investigated member of this group. The haemolytic uraemic syndrome was first described in 1955

\footnotetext{
Corresponding author: Assoc. Prof. Valentina Urumova, $\mathrm{PhD}$

E-mail address: valentina_62@ abv.bg

Present address: Department of Veterinary Microbiology,

Infectious and Parasitic Diseases

Faculty of Veterinary Medicine, Trakia University

6000 Stara Zagora, Bulgaria

Phones: 0035942699 603; 0035942649539
}

Copyright: (C) 2015 Urumova V. This is an open-access article published under the terms of the Creative Commons Attribution License which permits unrestricted use, distribution, and reproduction in any medium, provided the original author and source are credited.

Competing Interests: The authors have declared that no competing interests exist.

Available Online First: 7 November 2014

http://dx.doi.org/10.14432/j.macvetrev.2014.11.027 in Switzerland (2). Coli strains involved in the etiology of haemorrhagic uremic syndrome were also classified in the EHEC group. Levin et al. (3) determine the E. coli $\mathrm{O} 157: \mathrm{H} 7$ and $E$. coli $\mathrm{O} 26: \mathrm{H} 11$ serotypes as enterohaemorrhagic coli bacteria. Tzipori et al. (4) proposed also to include O4:NM, $\mathrm{O} 45: \mathrm{H} 2, \mathrm{O} 111: \mathrm{NM}$, and O145:NM serotypes to this group.

The term enterohaemorrhagic E. coli bacteria applies to strains, which, similar to E. coli $\mathrm{O} 157: \mathrm{H} 7$ produce one or more Shiga-like toxins, as well as possess a $60-\mathrm{MDa}$ plasmid linked to pathogenicity and are able to form $\mathrm{A} / \mathrm{E}$ type lesions in the intestinal mucosa. Like the enteropathogenic $E$. coli bacteria (EPEC), the members of the EHEC group initially adhere to intestinal mucosal surface in local areas, then adhere more deeply and destroy the intestinal microvilli. The initial adherence of EHEC is mediated by the $60-\mathrm{MDa}$ plasmid while the subsequent adherence to the mucosa is a chromosome-determined event.

Another feature of EHEC virulence is the production of Shiga-like toxin similar to that produced by Shigella dysenteriae type 1 . Konowalchuk detected shiga-producing $E$. coli as early as in 1977, before the elucidation of the role of toxins in bacterial virulence. He introduced the term 
verotoxins due to the cytotoxicity of strains when they are cultivated in Vero cells.

Both types of shiga-toxic factors, Shiga-like toxin I and Shiga-like toxin II, killing both Vero and HeLa cells, induce fluid accumulation in ligated rabbit intestinal loops, and are lethal for mice and rabbits $(5,6,7,8,9,10)$. Both toxic factors differ antigenically as well as with respect to their biological effect. The second shiga-like toxin is less toxic for Vero cells but at the same time, is more toxic for mice and causes hemorrhagic colitis in rabbits. Genes, determining the production of both toxins are located in bacteriophages, which allows obtaining the toxins from E. coli $\mathrm{O} 157: \mathrm{H} 7$ by transfer of bacteriophages. The genes responsible for the production of shiga-like toxin type I are similar to those encoding shiga-toxin production in Shigella, while the homology for shiga-like toxin type II is $58 \%$. It is believed that the shiga-like toxin produced by $E$. coli causing the pig oedema disease is a variant of shiga-like toxin type II which implies the existence of different cell receptors.

Dairy cattle are one of the main E. coli O157:H7 reservoirs $(11,12)$. Therefore, bovine foodstuffs are considered as important risk factor for human disease outbreaks. Animals are asymptomatic vectors for many representatives of the EHEC groups, and some E. coli strains other than EHEC could induce disease in young animals. For instance, the members of the O153 group cause a disease, similar to the human HUS in rabbits. The distal part of the rectum of so-called calves "super shedders" of E. coli $\mathrm{O} 157: \mathrm{H} 7$ is heavily colonized for a long period of time. A similar colonisation by E. coli O157:H7 could be observed in sheep. Animals, which are not natural reservoirs of this serotype could serve as secondary natural reservoirs. Apart from the consumption of contaminated foods, humans could be infected through contaminated water, direct contact with animals, with faecal masses and contaminated soils. The direct man to man transmission could occur during an epidemic. Human infections were described in connection with consumption of nonpasteurised goat milk, dry pork sausages, and after direct contact with horses, poultry and rabbits. It is assumed that the infectious doses for men could be less than 100 bacterial cells, even about 10 cells. Contaminated vegetables (spinach, lettuce, radishes) as well as non-pasteurised fruit juices could also pose a risk for infection to men. Data for contamination by herbs, e.g. parsley are reported. Drosophila melanogaster could spread the bacteria and in cases of impaired integrity of tissues, for instance in apples, the pathogens could develop.
It is acknowledged that E. coli $\mathrm{O} 157: \mathrm{H} 7$ could survive for 9 months in veal at $-20^{\circ} \mathrm{C}$. They exhibit a certain tolerance to acid environments, which could explain their persistence for weeks in mayonnaise, acid sauces, apple juice, and fresh cheeses at fringe temperatures. These bacteria are also resistance to drying. Cases of disease in humans are described also after swimming in pools and lakes (13).

With respect to the other EHEC serotypes, there are a lot of unexplained facts about their epidemiological status. For example, the main natural reservoirs of EHEC O26 are cattle, sheep, pigs, goats, rabbits and poultry. They are isolated from both healthy and diarrhoeic animals. Disease outbreaks in humans have been reported after consumption of beef products and non-pasteurised cow milk, as well as after direct contact with animals and drinking water contaminated with faeces.

EHEC O103 strains are isolated from calves, sheep, goats, as well as healthy and diseased humans (10). It could be claimed that EHEC O157: H- strains are rarely isolated from the feces of cattle and horses, although human outbreaks after consumption of sausage or close contact with infected cows and horses have been reported. This fact gave ground to believe that in such cases, humans could also serve as reservoir of infection (14).

The available data for the prevalence of VTEC in animals and food contamination rates in Europe originate from various sources, such as public health sector, veterinary and research labs. This complicates the analysis and necessitates coordination of programmes dealing with research on foods, official food control, monitoring programmes and research projects.

One of the first source of information with this regard was the European Community System for Monitoring and Collection of Information on Zoonoses, created by Council Directive 92/117/ECC. The directive includes the rules for sample collection, analysis and annual reporting associated with specific zoonoses, zoonotic agents in animals, foods and feeds in EC member states. In order to improve the information system, a new Zoonoses Directive 2003/99 was created, brought into force on 12 June 2004. At present, the system monitors 16 zoonoses, including VTEC.

Microbiological examinations associated to zoonotic agent monitoring could include the so-called sentinel studies, determining the trends in human morbidity rates, the so-called baseline prevalence in primary site of production and at a later stage, in the food chain, investigations on good production practices, determination of control 
Prevalence and antimicrobial resistance of enterohaemorrhagic Escherichia coli among dairy farms

measures' effect etc. The criteria of the EC Zoonoses Directive monitoring programmes include detection of the zoonotic agent in the animal population, in feeds, foods, the adverse effect in men, the economic impact for animals and human health, for the business related to feeds and foods production, epidemiological trends for animal populations, for men, feeds and foods.

Therefore, the investigation of VTEC O157 prevalence among animal populations and some foods of animal origin is a task of primary significance, which could consequently set the diagnostic strategy for investigation of the other factors. The purpose of the present study was to investigate for a two year period 2011-2013, the prevalence of $E$. coli $\mathrm{O} 157$ among cattle in some of the biggest farm in North Bulgaria, and to evaluate the sensitivity of isolates to some major classes of antibacterial drugs.

\section{MATERIAL AND METHODS}

\section{Number of samples}

For the period of the study, from January 2011 to May 2013, a total of 1094 faecal swab samples were obtained from cattle at different ages in four cattle farms in North Bulgaria - the villages Okorsh, Slavyanovo (municipality of Popovo), Dobri dol and Trem.

Samples were distributed as follows:

- Okorsh village - 300 swab samples (30 from heifers, 10 from dry cows, 10 from suckling calves, 50 from 6-month-old calves and 200 from cows);

- Slavyanovo village (municipality of Popovo) - 300 swab samples (30 from suckling calves, 100 from 6-month-old calves, 100 from heifers, and 70 from cows);

- Dobri dol village - 194 swab samples from calves 3 to 6 months of age;

- Trem - 300 swab samples (140 from calves 3 to 6 months of age; 70 from heifers and 90 from cows).

Nutrientmedia and microbiological consumables

The initial inoculation of swab samples was done on tryptic soy broth (Difco, USA) and McConkey agar with sorbitol (Difco, USA). For identification of sorbitol-negative coli bacteria on McConkey agar with sorbitol, indole motility medium (NCPID, Sofia) was used, as well as triple sugar iron agar medium (Merck, Germany), Simmons citrate agar
(NCPID, Sofia), the methyl rot and Voges-Proskauer tests, panels of BBL CRYSTAL (Becton Dickinson, USA) for identification of enterobacteria and nonfermenting bacteria. Isolates were serotyped by means of the agglutination test with E.coli O157 antiserum, Difco, USA, as per manufacturer's instructions.

The sensitivity of isolates to antimicrobial drugs was tested by disc-difusion method, on MullerHinton agar and antibiotic disks (Emapol, Poland). Antibiogrammes were done with the following disks: ampicillin $10 \mu \mathrm{g}$, cefotaxime $30 \mu \mathrm{g}$, ceftazidime $10 \mu \mathrm{g}$, gentamicin $10 \mu \mathrm{g}$, enrofloxacin $5 \mu \mathrm{g}$ and tetracycline $30 \mu \mathrm{g}$. Antibiogrammes were prepared in compliance with the Performance standards for antimicrobial disk and dilution susceptibility tests for bacteria isolated from animals, approved standard-Third Edition, M31-A3, №6, Clinical and Laboratory Standards Institute, Wayne, PA. The MICs to ampicillin and tetracycline were determined by the E-test, Liofilchem, Italy. The reference $E$. coli ATTC 25922 strain was used for disk diffusion test control and MICs determination (18).

\section{RESULTS}

Profile of sorbitol-negative strains isolated from the 4 studied farms

Out of the 1094 examined faecal swab samples, $36(3.3 \%)$ sorbitol-negative strains were isolated, which were positive in the agglutination test with E. coli $\mathrm{O} 157$ antiserum and were identified by the BBL CRYSTAL system as belonging to the $E$. coli O:157 serotype. The distribution of isolates was as followed:

- In the Okorsh cattle farm - 5 E. coli O: 157 isolates $(0.5 \%$, CL- $0.08 \% \div 0.9 \%)-2$ from cows and 3 from heifers;

- In the Slavyanovo farm - 7 E. coli O:157 isolates $(0.6 \%$, CL- $0.5 \% \div 0.7 \%)-2$ from calves 3 to 6 months of age and 5 from heifers;

- In the Dobri dol farm - 16 E. coli O:157 isolates $(1.5 \%$, CL- $1.2 \% \div 1.8 \%)$ - all from calves 3 to 6 months of age

- In the Trem farm-8 E. coli O:157 isolates $(0.7 \%$, CL- $0.6 \% \div 0.8 \%)-4$ from calves 3 to 6 months of age and 4 from heifers

The structural profile of E. coli O:157 isolates from the four studied farms is presented in Table 1. 
Urumova V. et al.

Table 1. Structural profile of cattle EHEC isolates

\begin{tabular}{lrrrr}
\hline & \multicolumn{3}{c}{ Number of samples/EHEC } \\
Age groups/studied & $\begin{array}{r}\text { Okorsh farm } \\
\text { number of }\end{array}$ & \begin{tabular}{r} 
Slavyanovo farm \\
number of \\
\cline { 2 - 4 } samples/EHEC
\end{tabular} & $\begin{array}{r}\text { Dobri dol farm } \\
\text { number of } \\
\text { samples/EHEC }\end{array}$ & $\begin{array}{r}\text { Trem farm } \\
\text { number of }\end{array}$ \\
Suckling calves & $10 / 0$ & $30 / 0$ & - & - \\
Calves 3-6 mo. of age & $50 / 0$ & $100 / 2$ & $194 / 16$ & $140 / 4$ \\
Heifers & $30 / 3$ & $100 / 5$ & - & $70 / 4$ \\
Cows & $210 / 2$ & $70 / 0$ & - & $90 / 0$ \\
TOTAL number of & $300 / 5$ & $300 / 7$ & $194 / 16$ & $300 / 8$ \\
samples/EHEC & & & & - \\
\hline
\end{tabular}

Investigations on the sensitivity of cattle EHEC isolates to antimicrobial drugs

Table 2 presents the results about the sensitivity of studied EHEC isolates from cattle to 6 antimicrobial drugs. The interpretation was in two groups - sensitive and resistant. The isolates in the respective groups are given in percent and confidence limits. When selecting the antibiotic disks, we focused on beta-lactam antibiotics and $3^{\text {rd }}$ generation cephalosporins with regard to the possibility for phenotyping isolates as producers of ESBL and AmpC enzymes, and we also included representatives of the different classes of antimicrobial drugs. The results were interpreted as per EUCAST recommendations (Epidemiological values).

The results from the disk diffusion test were presented through cumulative curves of ampicillin (Fig. 1) and tetracycline (Fig. 2) in resistant cattle EHEC isolates. The strains were $100 \%$ sensitive to the other tested antimicrobial drugs - oxyiminocephalosporins, gentamicin and enrofloxacin. From the 15 isolates resistant to tetracycline, 11 originated from the Dobri dol farm and 4 - from the other three farms. All seven ampicillin-resistant EHEC strains were from the Dobri dol farm.

Table 2. Sensitivity of cattle EHEC isolates to antimicrobial drugs

\begin{tabular}{lll}
\hline Antibacterial drugs & Sensitive isolates (\%)/CL & Resistant isolates (\%)/CL \\
\hline Ampicillin & $80.6 / 66.3 \div 91.6$ & $19.4 / 8.3 \div 33.6$ \\
Cefotaxime & 100 & - \\
Ceftazidime & 100 & - \\
Gentamicin & 100 & - \\
Tetracycline & $58.3 / 42.1 \div 73.6$ & $41.7 / 26.2 \div 57.9$ \\
Enrofloxacin & 100 & - \\
\hline \multicolumn{1}{c}{ Legend: $C L$ - Confidence limits } & & \\
\hline
\end{tabular}



Figure 1. Cumulative curve of ampicillin in cattle EHEC strains 


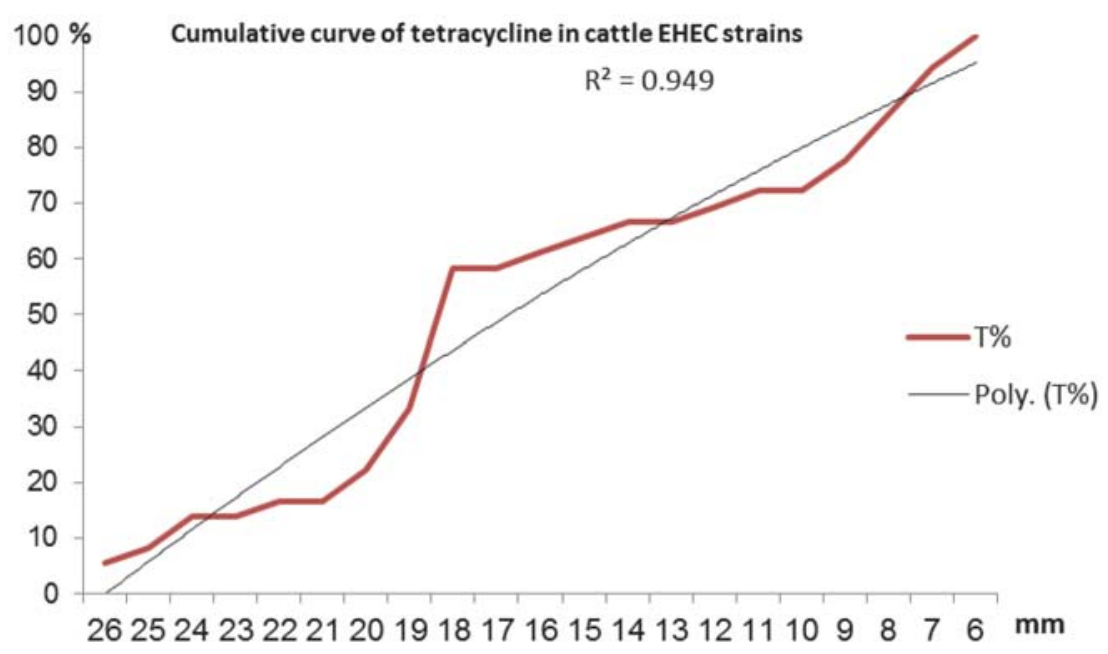

Figure 2. Cumulative curve of tetracycline in cattle EHEC strains

Figure 1 shows that the diameters of inhibition zones for ampicillin ranged between $22 \mathrm{~mm}$ and $6 \mathrm{~mm}$. A bimodal pattern of behaviour was present. The inhibition zones beyond which $50 \%$ and $90 \%$ of strains were located, were $18 \mathrm{~mm}$ and $7 \mathrm{~mm}$ respectively.

Figure 2 depicts that inhibition zones of tetracycline ranged between $26 \mathrm{~mm}$ and $6 \mathrm{~mm}$. The inhibition zones beyond which $50 \%$ and $90 \%$ of strains were located, were $19 \mathrm{~mm}$ and $7 \mathrm{~mm}$ respectively.

In connection with the resistance of EHEC isolates determined in the disk diffusion test to tetracycline (15 strains, $41.6 \%)$ and ampicillin (7 strains, 19.4\%), the MICs of both antibiotics were determined. The data are presented in Table 3. Out of the 7 ampicillin-resistant strains, 5 had MIC of 16 $\mu \mathrm{g} / \mathrm{mL}$, one - of $32 \mu \mathrm{g} / \mathrm{mL}$ and one - of $64 \mu \mathrm{g} / \mathrm{mL}$. Out of the 15 tetracycline isolates, 9 had MIC-of $16 \mu \mathrm{g} / \mathrm{mL}, 3$ - of $32 \mu \mathrm{g} / \mathrm{mL}, 2$ - of $64 \mu \mathrm{g} / \mathrm{mL}$ and 1 - of $128 \mu \mathrm{g} / \mathrm{mL}$.

\section{DISCUSSION}

The aforementioned circumstances determined that a major part of E. coli $\mathrm{O} 157$ infections in humans are associated with consumption of contaminated animal foods after inadequate thermal processing and/or the consumption of contaminated water $(19,20,21,22,23)$. Although the contamination at the farm level is believed to be minor (24), the risk for contamination of beef increases during transportation and the period of gathering of animals to slaughterhouses, and the end of the slaughter process. These facts are essential for investigations on the prevalence of EHEC in farm animals.

According to $\operatorname{EFSA}(15,17)$ the prevalence of VTEC among the population of Europe is very low, 1.2 per 100,000. Nevertheless, EFSA declared the intestinal bacterial pathogens to be important zoonotic agents, usually affecting children and elderly people. According to Hussein and Bollinger (16) the worldwide prevalence of VTEC O157 in fecal swab samples ranged between 0.2 and $27.8 \%$ and for VTEC, other than O157 - from 2.1 to $70.1 \%$.

Data from the international network Enter-net, founded by DG SANCO, European Commission in 2006 shows some differences in the data from EC countries with respect to VTEC infections. Regardless of the fact that more than $50 \%$ of EHEC infections in continental Europe are attributed to the 0157 serotype, and that for countries like Belgium, France, Finland, Hungary, Netherlands, Sweden, Spain, O157 is the main serotype (data from Enter-net, 2005), in Denmark, Germany, Italy,

Table 3. MIC of ampicillin and tetracycline in cattle EHEC strains

\begin{tabular}{|c|c|c|c|c|c|c|c|c|c|c|c|c|c|c|c|}
\hline \multirow{2}{*}{$\begin{array}{l}\text { Antimicrobial } \\
\text { Drugs }\end{array}$} & \multicolumn{15}{|c|}{$\mathrm{MIC} / \mu \mathrm{g} / \mathrm{mL}$} \\
\hline & 0.01 & 0.03 & 0.06 & 0.125 & 0.25 & 0.5 & 1 & 2 & 4 & 8 & 16 & 32 & 64 & 128 & 256 \\
\hline Ampicillin & & & & & & & & & & & 5 & 1 & 1 & & \\
\hline Tetracycline & & & & & & & & & & & 9 & 3 & 2 & 1 & \\
\hline
\end{tabular}


Norway and Luxemburg, other serotypes are more commonly reported. After the first epidemiological study on the prevalence of E. coli O157 among cattle, Montenegro et al. (25) affirmed that bovine population could be considered as the primary reservoir of VTEC. Other authors also suppose that cattle are the main reservoir of $E$. coli $\mathrm{O} 157: \mathrm{H} 7$, especially during the summer season $(26,27,28,29)$.

Low prevalence $(0.28 \%)$ of E. coli $\mathrm{O} 157$ was established among cattle in the USA (29). In a 15-month survey on the prevalence of coli bacteria from the 0157 serotype among the different categories of cattle at one farm, Mechie et al. (30) demonstrated a prevalence between $0 \%$ and $13.5 \%$ in dairy cows, between $0 \%$ and $68 \%$ in heifers and between $0 \%$ and $56.3 \%$ in calves. In our studies, we also observed EHEC in calves aged 3 to 6 months in three of the four studied farms $(4.5 \%)$, and in heifers in three of farms $(6 \%)$.

A critical analysis of data from 26 epidemiological surveys on the presence of $E$. coli O157:H7 among cattle in different regions of the world was performed (31). The data for North America showed that a prevalence for dairy cows of $7-8 \%$ and a high prevalence among feedlot calves $-61 \%$. In the same analysis however, other data from USA showed a low E. coli $\mathrm{O} 157: \mathrm{H} 7$ incidence in suckling calves $(1.5 \%)$ and varying values in calves older than 8 months $(1.8 \%$ to $5 \%)$. The prevalence among heifers was $2.3 \%$, while in adult cows, it declined markedly up to $0.7 \%$. In the opinion of the authors, data originating from Europe also evidenced a higher prevalence among younger animals. In adults, the incidence of E. coli $\mathrm{O} 157: \mathrm{H} 7$ was between 0 and $1 \%$. We could hardly compare our data with those reported by Broseta et al. (31) $4.5 \%$ prevalence for calves 3-6 months, $6 \%$ for heifers and $0.5 \%$ for cows, as the information of the latter refers to a high number of farms, but it could be stated anyway that reported rates are comparable.

The investigations on the subject, carried out in different regions of the world $(26,28,32,33)$ also established higher prevalence of EHEC O157:H7 in calves aged 3 - 6 months. Hancock et al. (22) believe that heifers carried a significant amount of EHEC O157:H7 (CFU/g), compared to other categories of cattle. Ezawa et al. (34) outlined that the overall prevalence of EHEC O157:H7 among cattle in Japan (5-10\%), but that heifers exhibited higher rates (32-46\%). In Italy, a prevalence of $16 \%$ among cows was reported (35). According to Wray et al. (36), the shedding of EHEC in adult cows was shorter and no more than 2 weeks, whereas the shedding in weaned calves lasted for more than 58 days. Alali et al. (37) affirmed that in calves 26 experimentally infected with EHEC O157:H7, and calves fed milk replacer, an enhanced shedding of the pathogen occurred on the $6^{\text {th }}$ and $10^{\text {th }}$ day after the infection compared to calves fed milk. In England and Wales, Paiba et al. (38) reported EHEC O157:H7 prevalence rates at the farm level within a large range (from $1 \%$ to $51 \%$,) with highest percentage among calves 2-6 months of age and lowest rates - among calves up to 2 months of age. In the Netherlands, the 2-year survey at the slaughterhouse level showed a $10 \%$ prevalence of EHEC serotype 0157 in cows (39).

In comparison with the data of Johnsen et al. (40) evidencing a lower individual prevalence of E. coli $\mathrm{O} 157: \mathrm{H} 7$ - 0.19\% and a correspondingly lower prevalence at the farm level $(0.35 \%)$ in 15421 cattle in Norway, our data for the prevalence of coli bacteria from the 0157 serotype in studied cattle at the farm level was higher, for Okorsh farm it was $1.6 \%$, for Slavyanovo $-2.3 \%$, Dobri dol $-8.2 \%$ and for Trem- $2.6 \%$.

The $\mathrm{PhD}$ thesis of Eriksson, Swedish University of Agricultural Sciences, Uppsala (41) has determined a prevalence of EHEC O157 in cattle at slaughterhouses for 2008-2009 of 3.3\%, which agrees completely with our data for the two-year survey period, as well as with respect to the total number of examined faecal swab samples.

In the USA, it found out that $70 \%$ of EHEC 0157 isolates from cattle were resistant to streptomycin, sulfamethoxazole and tetracycline (42). Furthermore, the authors included the resistance of ampicillin, kanamycin and ticarcillin in resistant phenotype profiles of coli bacteria. With respect to the sensitivity of $E$. coli isolates, the data from the present study are comparable to those of other authors $(42,43)$, except for the reported resistance to ceftazidime. In this study, the authors sought differences with respect to antimicrobial resistance of enterohaemorrhagic E. coli on the basis of the super-shedding $\left(\leq 10^{4} \mathrm{CFU}\right)$ and low-shedding criteria. In the first group of isolates they determined resistance to ceftazidime, and for both groups the most common phenotype profiles included ampicillin, sulfamethoxazole, streptomycin and tetracycline, as well as the combination trimethoprim/sulfamethoxazole. Similar to the data from the present study, they did not observe resistance of enrofloxacin in studied coli strains. In Korea, You et al. (44) determined that cattle EHEC 0157 were most frequently resistant to streptomycin, tetracycline, sulfamethoxazole, ampicillin, kanamycin, cefalotin, ticarcillin and sulfamethoxazole. 
Prevalence and antimicrobial resistance of enterohaemorrhagic Escherichia coli among dairy farms

The resistance to beta-lactam antimicrobial drugs is essential for trends for the spread of coli bacteria producing beta-lactamases with broader spectrum of activity. In our study, in contrast to the aforementioned data, studied EHEC O157 strains showed no resistance to cephalosporins. In the USA, Fitzgerald et al. (45) reported that cattle EHEC 0157 isolates were resistant first to tetracyclines, and second, to spectinomycin, ampicillin and sulfonamides. They neither found out resistance to cephalosporins. Data about the sensitivity of cattle, pig and human EHEC 0157 isolates to antimicrobial drugs were published in South Africa (46). Cattle isolates demonstrated the highest percent of resistance to sulfamethoxazole $(100 \%)$, tetracycline $(100 \%)$, ampicillin $(25 \%)$ and streptomycin $(50 \%)$. The spread of resistance to tetracyclines, aminoglycosides, sulfonamides and lactam antibiotics in a number of intestinal bacteria occurs through integrons transfer by conjugation, facilitating the rapid dissemination among bacteria (47). Considering these events, another important aspect in studies on the prevalence of zoonotic agents among animal populations is the investigation of their resistance to antimicrobial drugs. Having in mind the public importance of this phenomenon, a number of regulations have been issued by the EC institutions for monitoring of resistance to various chemotherapeutic groups, which are essential for the out-hospital spread of resistance. Therefore, our study's emphasis was placed on the markers of resistance to oxyimino-cephalosporins due to the recent wide public discussion on the topic in European countries (48).

\section{CONCLUSION}

The prevalence of $E$. coli $\mathrm{O} 157$ between cattle in the four investigated farms in the North part of Bulgaria are low for cows $0.5 \%$, in contrast with the prevalence of this serotype for heifers $6 \%$ and for calves $4.5 \%$.

Taking into consideration the fact that the period and the scope of our survey were limited, the negative results with regard to the resistance of coli bacteria to $3^{\text {rd }}$ generation cephalosporins could hardly be interpreted as optimistic. Moreover, there are data at a national level about the approval and use of cefquinome in dairy cattle farming and ceftiofur in pig farming, which are prerequisites for selective pressure and possibly at the background of the onset and spread of resistance to cephalosporins. At the Dobri dol farm, the resistance of ampicillin and tetracycline is a reliable proof for future trends, taking into account the mutation diversity with respect to beta lactamase enzymes.

\section{REFERENCES}

1. Riley, L.W., Remis, R.S., Helgerson, S. D. (1983). Hemorrhagic colitis associated with a rare Escherichia coli serotype. N. Engl. J. Med. 308, 681-685. PMid:6338386

2. Gasser, C., Gautier, E., Steck, A., Siebenmann, R.E., Oechslin, R. (1955). The haemolytic-uraemic syndrome. Schweiz. Med. Wschr. 85, 905 PMid:13274004

3. Levine, M. M., Xu, J., Kaper, J. B. (1987). A DNA probe to identify enterohemorrhagic Escherichia coli of $\mathrm{O} 157: \mathrm{H7}$ and other serotypes that cause hemorrhagic colitis and haemolytic uremic syndrome. J. Infect. Dis. 156, 175-182.

http://dx.doi.org/10.1093/infdis/156.1.175 PMid:3298451

4. Tzipori, S., Wachsmuth, I. K., Smithers, J. (1988). Studies in gnotobiotic piglets on non - O157:H7 Escherichia coli serotypes isolated from patients with hemorrhagic colitis. Gastroenterology 94, 590-597. PMid:3276573

5. Knutton, S., Baldwin, T., Williams, P. H. (1989). Actin accumulation at sites of bacterial adhesion to tissue culture cells: basis of a new diagnostic test for enteropathogenic and enterohemorrhagic Escherichia coli. Infect. Immunology 57, 1290-1298.

PMid:2647635; PMCid:PMC313264

6. March, S. B., Ratnam, S. (1986). Sorbitol-MacConkey medium for detection of Escherichia coli O157:H7 associated with hemorrhagic colitis. J. Clin. Microbiol. 23, 869-872.

PMid:3519658; PMCid:PMC268739

7. Walker, C. W., Upson, R., Warren, R. E. (1988). Hemorrhagic colitis: detection of verotoxin producing Escherichia coli O157:H7 in a clinical microbiology laboratory. J. Clin. Pathol. 41, 80-84. http://dx.doi.org/10.1136/jcp.41.1.80 PMid:2685050; PMCid:PMC501874

8. Chapman, P. A. (1989). Evaluation of commercial latex slide test for identifying Escherichia coli O157. J. Clin. Pathol. 42, 1109-1110. http://dx.doi.org/10.1136/jcp.42.10.1109 PMid:2685050; PMCid:PMC501874

9. Borczyk, A. A., Lior, H., Thomson, S. (1989). Sorbitol-negative Escherichia coli O157 other than H7. J. Infect. 18, 198-199. http://dx.doi.org/10.1016/S0163-4453(89)91486-2

10. Dorn, C. R., Scotland, S. M., Smith, H. (1989). Properties of Vero cytotoxin- producing Escherichia coli of human and animal origin belonging to serotypes other than O157:H7. Emidemiol. Infect. 103, 83-95.

http://dx.doi.org/10.1017/S0950268800030387

PMid:2673828; PMCid:PMC2249490 
11. Davis, M. A., Daniel, H. R., Haiqing, S. (2006). Comparison of cultures from rectoanal-junction mucosal swabs and feces for detection of Escherichia coli O157 in dairy heifers. Appl. Environ. Microbiol. 72(5): 3766-3770.

http://dx.doi.org/10.1128/AEM.72.5.3766-3770.2006 PMid:16672532; PMCid:PMC1472398

12. Schouten, J.M., Graat, E.A., Frankena, K., Van Zijderveld, F., De Jong, M.C. (2009). Transmission and quantification of verocytotoxin-producing Escherichia coli $\mathrm{O} 157$ in dairy cattle and calves. Epidemiol. Infect. 137(1): 114-123. http://dx.doi.org/10.1017/S0950268808000320 PMid:18346284

13. Friedman, M. S., Roels, T., Koehler, J. E., Feldman, L., Bibb, W. F., Blake, P. (1999). Escherichia coli O157:H7 outbreak association with improperly chlorinated swimming pool. Clin. Infect. Dis. 29, 298-303. http://dx.doi.org/10.1086/520204 PMid:10476731

14. World Organisation for Animal Health (OIE). (2008). Manual of diagnostic tests and vaccines for terrestrial animals. Paris: OIE; Verocytotoxigenic Escherichia coli.

15. Europian Food Safety (EFSA). (2007). Monitoring of Verotoxigenic Escherichia coli (VTEC) and identification of human pathogenic VTEC types. Scientific Opinion of the Panel on Bilogical Hazards. EFSA J. 579, 1-61.

16. Hussein, H. S., Bollinger, L. M. (2005). Prevalence of Shiga toxin-producing E. coli in beef cattle. J.Food Prot. 68, 2224-2241. PMid:16245735

17. Europian Food Safety (EFSA) Scientific Report of EFSA (2009). Technical specifications for the monitoring and reporting of verotoxigenic Escherichia coli (VTEC) on animals and food (VTEC surveys on animals and food). EFSA J. 7 (11): D-RN-520.

18. CLSI. (2006). Performance standards for antimicrobial disk and dilution susceptibility tests for bacteria isolated from animals, approved standardThird Edition, M31-A3, №6, Clinical and Laboratory Standards Institute, Wayne, PA.

19. Isaäcson, M., Canter, P.H., Effler, P., Arntzen, L., Bomans, P., Heenan, R. (1993). Haemorrhagic colitis epidemic in Africa. Lancet 341, 961. http://dx.doi.org/10.1016/0140-6736(93)91253-I

20. Paquet, C., Petea, W., Grimont, E., Collin, M., Guillod, M. (1993). Aetiology of haemorrhagic colitis epidemic in Africa. Lancet 342, 175. http://dx.doi.org/10.1016/0140-6736(93)91378-Y

21. Armstrong, G. L., Hollingsworth, J., Morris, J. R. (1996). Emerging foodborne pathogens Escherichia coli O157:H7as a model of entry of a new pathogen into the food supply of the developed world. Epidemiology Review 18, 29-51. http://dx.doi.org/10.1093/oxfordjournals.epirev.a017914 PMid:8877329
22. Müller, E. E., Ehlers, M. M., Grabow, W. O. K. (2001). The occurrence of E. coli O157:H7 in Southern African water sources intended for direct and indirect human consumption. Water Research 35, 3085- 3088. http://dx.doi.org/10.1016/S0043-1354(00)00597-2

23. Olsen, S. J., Miller, G., Breuer, I., Kennedy, M., Higgins, C., Walford, J., Mckee, G., Fox, K., Bibb, W., Mead, P. (2002). A waterborne outbreak of Escherichia coli $\mathrm{O} 157: \mathrm{H} 7$ infections and haemolytic uraemic syndrome: implications for rural water systems. Emerging Infectious Diseases 8, 370-375. http://dx.doi.org/10.3201/eid0804.000218 PMid:11971769; PMCid:PMC2730238

24. Jordan, D. (1998). Pre-slaughter control of beef carcass contamination with Escherichia coli O157:H7: a risk assessment approach. PhD thesis, Univ. of Guelph, Guelph Canada, pp. 236.

25. Montenegro, M., Bülte, M., Trumpf, T., Aleksic, S., Reuter, G., Bulling, E., Helmuth, R. (1990). Detection and characterization of fecal verotoxin- producing Escherichia coli from healthy cattle. J Clinic. Microbiol. 28 (6): 1417-1421.

PMid:2199502; PMCid:PMC267942

26. Wells, J. G., Shipman, L. D., Greene, K. D., Sowers, E. G., Green, J.H., Cameron, D. N., Downes, F.P., Martin, M.L., Griffin, P. M., Ostroff, S. M., Potter, M. E., Tauxe, R. V., Washsmuth, I. K. (1991). Isolation of Escherichia coli O157:H7 and other Shiga-like-toxin-producing E. coli from dairy cattle. J. Clin. Microbiol. 29, 985-989.

PMid:2056066; PMCid:PMC269920

27. Chapman, P. A., Siddons, C. A., Malo, A. T. C., Harkin M. A. (1997). A one-year study of Escherichia coli $\mathrm{O} 157$ in cattle, sheep, pigs and poultry. Epidemiol. Infect. 119, 245-250.

http://dx.doi.org/10.1017/S0950268897007826 PMid:9363024; PMCid:PMC2808847

28. Zhao, T., Doyle, M. P., Shere, J., Garber, L. (1995). Prevalence of enterohemorrhagic Escherichia coli O157:H7 in a survey of dairy herds. Appl. Envioron. Microbiol. 61, 1290-1293.

PMid:7747951; PMCid:PMC167385

29. Hancock, D. D., Besser, T. E., Kinsel, M. L., Tarr, P. I., Rice, D. H., Paros, M. G. (1994). The prevalence of Escherichia coli O157:H7 in dairy and beef cattle in Washington State. Epidemiol. Infect. 113. 199-207. http://dx.doi.org/10.1017/S0950268800051633 PMid:7925659; PMCid:PMC2271540

30. Mechie, S. C., Chapman, P. A., Siddons, C. A. (1997). A fifteen month study of Escherichia coli O157:H7 in a dairy herd. Epidemiol. Infect. 118, 17-25. http://dx.doi.org/10.1017/S0950268896007194 PMid:9042031; PMCid:PMC2808768 
31. Broseta, S. M., Bastian, S. N., Arné, P. D., Cerf, O., Sanaa M. (2001). Review of epidemiological surveys on the prevalence of contamination of healthy cattle with Escherichia coli sero group O157:H7. Int. J. Hyg. Environ. Health 203, 347-361. http://dx.doi.org/10.1078/1438-4639-4410041 PMid:11434215

32. Cray, W. C., Moon, H.W. (1995). Experimental infection of calves and adult cattle with Escherichia coli O157:H7. Appl. Environ. Microbiol. 61, 1586-1590. PMid:7747972; PMCid:PMC167413

33. Hancock, D. D., Besser, T. E., Rice, D. H., Herriot, D. E., Tazz, D. I. (1997). A longitudinal study of Escherichia coli $\mathrm{O} 157$ in fourteen cattle herds. Epidemiol. Infect. 118, 193-195.

http://dx.doi.org/10.1017/S0950268896007212

PMid:9129597; PMCid:PMC2808780

34. Ezawa, A., Gocho, F., Kawata, K., Takahashi, T., Kikushi, N. (2004). High prevalence of enterohemorrhagic Escherichia coli (EHEC) 0157 from cattle in selected region of Japan. J.Vet. Med. Sci. 66, 585-587.

http://dx.doi.org/10.1292/jvms.66.585

PMid:15187376

35. Bonardi, S., Maggi, E., Bottarelli, A., Pacciarini, M. L., Ansuini, A., Vellini, G., Morabito, S., Caprioli, A. (1999). Isolation of Verocytotoxin - producing Escherichia coli 0157:H7 from cattle at slaughter in Italy. Vet. Microbiol. 67: 203-211. http://dx.doi.org/10.1016/S0378-1135(99)00039-5

36. Wray, C., McLaren, I. M., Randall, L. D., Pearson, G. R. (2000). Natural and experimental infection of normal cattle with Escherichia coli 0157:H7. Vet. Rec. 147: 65-68.

http://dx.doi.org/10.1136/vr.147.3.65

PMid:10958486

37. Alali, W. Q., Sargeant, J. M., Nagaraja, T. G., De Bey, B. M. (2004). Effect of antibiotics in milk replacer on fecal shedding of Escherichia coli 0157:H7 in calves. J. Anim. Sci. 82, 2148- 2152. PMid:15309963

38. Paiba, G. A., Willsmith, J. W., Evans, S. J. et al. (2003). Prevalence of fecal excretion of Verocytotoxigenic Escherichia coli 0157 in cattle in England and Wales. Vet. Rec. 153, 347- 353.

http://dx.doi.org/10.1136/vr.153.12.347

PMid:14533765

39. Heuvelink, A. E., Van Biggelaar, F. L., De Boer, E., Herbes, R. G., Melchers, W. J., Huis, I. T., Veld, J. H., Monnens, L. A. (1998). Isolation and characterization of verocytotoxin-producing Escherichia coli 0157 strains from Dutch cattle and sheep. J. Clin. Microbiol. 36, 878-882.

PMid:9542902; PMCid:PMC104654
40. Johnsen, G., Wasteson, Y., Heir, E., Berget, I. O., Herikstad, H. (2001). Escherichia coli O157:H7 in feces from cattle, sheep and pigs in southwest part of Norway during 1998 and 1999. Int. J. Food Microbiol. 65, 193-200. http://dx.doi.org/10.1016/S0168-1605(00)00518-3

41. Eriksson, E. (2010). Verotoxinogenic Escherichia coli O157:H7 in Swedish cattle and pigs. Doctoral Thesis, Swedish University of Agricultural sciences, Upsala.

42. Meng, J., Zhaos, S., Doyle, M. P., Joseph, S. W. (1998). Antibiotic resistance of Escherichia coli 0157:H7 and 0157: NM isolated from animals, food and humans. J. Food Prot. 61(1): 1511-1514.

PMid:9829195

43. Stanford, K., Agopsowicz, C. A., McAllister, T. A. (2012). Genetic diversity and antimicrobial resistance among isolates of Escherichia coli 0157:H7 from feces and hides of super shedders and low-shedding pen -mates in two commercial beef feedlots. BMC Vet. Rec. 8, 178.

http://dx.doi.org/10.1186/1746-6148-8-178 PMid:23014060; PMCid:PMC3582550

44. You, I. Y., Moon, B. M., Oh, I. G., Back, B. K., Li, L. G. et al. (2006). Antimicrobial resistance of Escherichia coli 0157 from cattle in Korea. Int. J. Food Microbiol. 106 (1): 74-78. http://dx.doi.org/10.1016/j.ijfoodmicro.2005.05.013 PMid:16300850

45. Fitzgerald, A. C., Edrington, T. S., Looper, M. L., Callaway, T. R. et al. (2003). Antimicrobial susceptibility and factors affecting the shedding of Escherichia coli 0157:H7 and Salmonella in dairy cattle. Letters in Applied Microbiology 37, 392-398. PMid:14633110

46. Ateba, C. N., Bezuidenhout, C. C. (2008). Characterisation of Escherichia coli 0157 strains from humans, cattle and pigs in the North- West Province, South Africa. Int J Food Microbiol. 128 (2): 181-8. http://dx.doi.org/10.1016/j.ijfoodmicro.2008.08.011 PMid:18848733

47. Zhao, S., White, D. C., Ayers, G. B., Friedman, S. et al. (2001). Identification and characterization of integrin-mediated antibiotic resistance among shigatoxin-producing Escherichia coli isolates. Appl. Environ. Microbiol. 67, 1558- 1564. http://dx.doi.org/10.1128/AEM.67.4.1558-1564.2001 PMid:11282605; PMCid:PMC92769

48. Efsa Panel on Biological Hazards (BIOHAZ). (2011). Scientific opinion on the public health risks of bacterial strains producing extended-spectrum $\beta$-lactamases and/or AmpC $\beta$-lactamases in food and food-producing animals. EFSA J. 9 (8): 2322. 